\title{
SELECTED VARIABLES RELATED TO THE QUALITY OF LIFE IN CANCER
}

\begin{abstract}
The aim of this article is to present cancer as a serious, life-threatening chronic disease that strongly impacts all aspects of a patient's quality of life, including the physical, psychological, social, and spiritual ones. This theoretical article describes selected variables related to the quality of life of a cancer victim during the processes of diagnosis and treatment. These variables include stress and coping with the specific stress of having cancer, appraisal of the disease, acceptance of illness, and social support. Also discussed is the role of the variables listed above in quality of life in cancer and current research on these connections. Implications of the presented theory and research indicate that cancer affects quality of life in all areas and that the process of adaptation to the disease is facilitated by adopting adaptive coping strategies, appraising the disease as a challenge rather than as a threat or loss, accepting the inevitable limitations to everyday life, and seeking and using various sources of social support.
\end{abstract}

Keywords: quality of life, cancer, coping with stress, illness' appraisal, acceptance, social support.

\section{INTRODUCTION}

Cancer as a psychosomatic, systemic and multifaceted disease carries a great threat to the quality of life in many aspects, including physical, social, mental and spiritual. Illness puts a man before dealing with fear of the future and death. Stress affects a sick person at all stages of treatment, starting with the decision to consult a physician about disturbing symptoms, undergoing diagnostic tests and treatment, as well as in the period after treatment. Cancer is often seen as a systemic disorder that results from an imbalance in the biological, psychological, social and spiritual dimensions. However, the involvement of psychological factors in the initiation and course of cancer is not yet fully understood (Chojnacka-Szawłowska, 2012).

The type of cancer, stage of the disease, biological properties and effects of treatment affect the emotional responses of patients to the disease. At the psychological level, cancer causes uncertainty, an unstable emotional state of a sick person, a change in the perspective of the future and carries the risk of dying and death. At the spiritual level, cancer puts you in a position to rethink your personal values and the importance of life. At the interpersonal level, cancer threatens a sense of belonging to a family, close relationships and relationships

\footnotetext{
1 Agata Wolanin, PhD, Rzeszow University of Technology, The Faculty of Management, Department of Humanities and Social Sciences, 12 Powstańców Warszawy Ave., 35-959 Rzeszów; e-mail: a.wolanin@prz.edu.pl. ORCID: 0000-0001-7679-9232.
} 
with society, such as work or social activity, and evokes a sense of abandonment, loneliness, marginalization and even stigmatization. The impact of the above factors on patients' quality of life varies depending on the phase of the disease and its course (Grassi et al., 2007). In the biological sphere, cancer causes discomfort associated with the side effects of the disease and its treatment. In the psychological area, the impact of the disease concerns personality and the use of coping strategies. Cancer in this sphere contributes to the feeling of anxiety, as well as to asking questions about the meaning of life. In the social area, however, it affects social relations. Because cancer is a systemic disease, the various factors in this model (biological, social, and psychological and spiritual) have common areas affected by the disease (Grassi et al., 2007).

A general psycho-oncology research model is presented by Jimmie Holland (1998). The independent variables include cancer understood as a disease process and treatment effects. The dependent variables include the quality of life in the areas of: physical, psychological, social, professional and sexual, and the traditionally recognized variable, which is survival time. Holland also distinguishes 4 categories of mediating variables in this model that modify the impact of disease and treatment on quality of life and survival. The first category includes personal variables: socio-demographic data, personality and styles of dealing with personal problems, including ways of dealing with difficult situations as well as previous life experiences, life attitudes, sense or lack of meaning and purpose of life, faith, religion, worldview. The second category of mediating variables are medical variables, such as doctor-patient relationships, treatment context, patient's choice of treatment and rehabilitation, and patient behavior towards disease and treatment. The third category includes social variables, i.e. social support and the role of the family. The fourth category refers to variables related to stress of life (e.g. concomitant diseases, loss situations, accumulation of life-threatening life events in a short time). According to Holland, determining the role and importance of mediating variables of this model for shaping the quality of life of people suffering from cancer will allow both to explain the impact of the disease on the quality of life, but also to develop principles and techniques of influencing patients to improve their quality of life. Holland's model takes into account interventions affecting mediating variables, including known psychotherapeutic forms and crisis interventions, as well as new forms of help specific to psycho-oncology.

\section{STRESS DURING THE DIAGNOSIS AND TREATMENT OF CANCER}

The quality of life in cancer patients depends largely on the stress they experience from the disease and its treatment. Tumors are seen as extremely stressful diseases. Many patients experience symptoms of stress occurring in the form of depression, anger and anxiety associated with the progression of the disease and the threat of death. Juczyński (2000) presented a stress model for cancer patients related to the diagnosis, treatment period and time after cancer treatment. Diagnosis of the disease is usually a process that starts with suspecting the possibility of the disease occurring. Stress associated with suspicion of cancer occurs as a result of observing certain symptoms of the disease and the associated need to decide whether to undergo diagnostic tests. Some people treat all disturbing symptoms as a clear signal of cancer, others downplay them. Stress associated with noticing the symptoms of the disease causes the use of specific coping strategies. It can be acceptance, which increases fear and anxiety, which is associated with the assumption that 
it is definitely cancer. Another strategy is to deny the existence of a potential disease, which gives temporary relief and reduces negative emotions (Juczyński, 2000).

Diagnosis of cancer is associated with patient confrontation with a real threat to life. Therefore, undergoing diagnostics and verification of unclear symptoms can cause severe anxiety and, as a consequence, avoid and delay contact with a doctor, temporarily giving a sense of comfort (Chojnacka-Szawłowska, 2012).

After deciding to undergo diagnostics, there is a stage of stress related to testing. It is stressful for the patient to test and wait for the results. The patient's attention is absorbed by the current situation and waiting for its clarification. A negative test result, excluding cancer, causes relief and discharge of emotions, while a positive result leads to the next stage - stress associated with confirming the disease.

The most obvious effects of confirming cancer are depression and anxiety (Juczyński, 2000). The diagnosis of a malignant tumor meets the criteria of and may contribute to posttraumatic stress disorder (APA, 1994, after: Chojnacka-Szawłowska, 2012). Also earlier traumatic experiences may cause a more negative assessment of the disease situation and worse adaptation to treatment (Chojnacka-Szawłowska, 2012). It is estimated that 40-60 percent of cancer patients have symptoms that meet the criteria for adaptive disorders, depression or post-traumatic stress disorder (after Grassi et al., 2007).

At this stage, most patients go through the stages of emotional responses to the disease described by Kübler-Ross (1979). The first of these is shock and disbelief, which lead to the formulation of denials (e.g. "it's impossible; it can't be cancer"). Another reaction is anger and self-resentment. It is the result of realizing the fact of getting sick and is accompanied by the question "Why me?", "Why it happened to me?". The next stage of reaction to the disease is depression and despair, anxiety, helplessness and anger with crying, sleep and appetite disorders. This causes temporary inability to perform their current roles. This phase can last for many weeks, but most patients accept the new situation over time and achieve good adaptation. The presented course and order of the stages of reaction to the disease is not rigid. Some quickly reach the final stage of acceptance, while others remain in the earlier stages of experiencing emotions that are reaction to the disease for a long time.

The next stage which is the source of strong stress is the period of treatment of the disease. Stress in this phase is associated with the treatment used and its side effects. One of the greatest stressors is stay in the hospital itself (Cohen and Lazarus, 1979, after: Juczyński, 2000). The most important problems causing stress during hospitalization are difficulties in information processing, in the scope of doctor-patient communication and in access to social support. Stress reduces memory capacity and difficulties in understanding new terms provided by medical staff. This promotes a sense of threat and ignorance about the course of the disease and its treatment and prognosis. Patient's trust in the doctor and support from relatives are of great importance in the treatment process (Juczyński, Szamburska and Czechowicz, 1997). The high quality of communication between the doctor and patient facilitates consent to treatment and compliance with recommendations. In turn, detachment from one's own environment and contacts with loved ones increases stress.

Stress is also caused by the type of treatment used. The basic methods of treatment include surgery, chemotherapy and radiation (Juczyński, 2000). Anxiety associated with the procedure is caused, among others, by the expected treatment result, expected complications, narcosis, fear of losing control over one's own behavior after the drugs used 
(de Walden-Gałuszko, 2011). Operations in cancer patients cause more anxiety in anticipation of surgery and greater sense of powerlessness after surgery than in patients suffering from other diseases. Some patients willingly accept drastic surgery, expecting greater effectiveness and chances for recovery after it. Surgical procedures cause changes in the image of self and body, they also cause changes in social and sexual functioning. They also affect marital and professional relationships and cause anxiety in social situations (Silberfarb and Greer, 1982). Mutilation is particularly stressful, such as limb amputation, stoma, gynecological tumors resulting from infertility or removal of facial tumors. Stress associated with surgery may exacerbate the course of diseases for psychiatric patients, e.g. schizophrenia, affective disorder and anxiety neurosis (de Walden-Gałuszko, 2011).

Nausea and vomiting are among the most stressful effects of chemotherapy. About 25 percent of patients develop these symptoms by conditioning them by associating unpleasant symptoms with a hospital room, smell, etc. (Juczyński, 2000). Other side effects that constitute a stressful situation for the patient include hematological changes, hair loss and sexual disorders, including menopause and infertility (de Walden-Gałuszko, 2011). Patients undergoing chemotherapy treatment often experience anxiety, resentment, anger and depression. There are also cognitive, emotional, psychomotor disorders, consciousness disorders and decreased libido (de Walden-Gałuszko, 2011). Stress occurring during radiotherapy may be associated with a sense of "mystery" of this method of treatment, an idea of the harmfulness of radiation, thinking about "inoperable" cancer, fear of radiation overdose or failure of the apparatus (de Walden-Gałuszko, 2011).

The last stage of stress associated with the disease is the post-treatment phase. The period after treatment is sometimes perceived by patients as a threat of recurrence of the disease, and in some patients this stress does not even eliminate complete cure. Experience of the disease often causes psychological and social problems for many months or even years to come. On the other hand, some people also experience positive changes at this time, for example, a reevaluation of life (Juczyński, 2000).

Both the diagnosis of the disease and its treatment are a difficult situation and require mental adaptation. Patient resources, such as the strategies used to manage stress in the face of a serious illness and the ability to accept the current situation, and social resources in the form of support facilitate adaptation to the situation of the disease and can promote a higher quality of life.

\section{COPING WITH CANCER}

The concept of coping treated as a conscious strategy of responding to stressful events appeared in the early 1970s. The most important theoretical approaches to coping with disease stress include the stress transactional concept of Lazarus and Folkman (1984), Hobfoll's theory of resource conservation (2006) and Schwarzer's future-oriented coping (2001).

Hobfoll's theory of conservation of resources (2006) says that people strive to obtain, maintain, protect and develop valuable things, i.e. resources. Stress appears in the event of a loss of resources or threat of loss, and in the absence of an increase in resources after investing them. Loss of resources has a much greater impact on a person's well-being than their profit. A disease situation is often a threat of loss, a real loss of resources, and a lack of profit when investing resources in treatment. 
Schwarzer's future-oriented coping concept (2001) includes anticipative coping (focused on a difficult event that will certainly occur soon), preventive coping (applies to negative events that may or may not occur in an undefined future) and proactive coping (includes building resources, personal development for future challenges, not the current threat situation). In a disease situation, in addition to reactive coping, there is also futureoriented coping, e.g. aroused by fear of disease deterioration or recurrence.

One of the theories most commonly used to explain coping with disease stress is the cognitive concept of Lazarus and Folkman. According to the transactional stress theory of Lazarus and Folkman (1984), in a stressful situation a person makes a primary and secondary appraisal of stress sources and coping possibilities. Stress in this approach is a complex relationship of disturbing the balance between requirements and capabilities, assessed by a person as exceeding resources or threatening well-being. The initial appraisal of the stressful situation includes assessment as a threat, challenge and harm / loss. Possibilities of removing the causes of stress, alleviating its effects, are made during so-called secondary appraisal, i.e. assessment of stress sources and own resources. To restore balance between themselves and the environment, man assesses his competences, material resources and social support. Performing a secondary appraisal may prompt you to take an activity related to changing the stress transaction, called coping with stress. In Lazarus and Folkman's theory, coping means "the cognitive and behavioral efforts of the subject to meet specific external and / or internal requirements, assessed as exhausting or exceeding the resources of the individual" (after: Heszen- Niejodek, 2000).

The authors of the concept presented two functions of coping. The first is the task function and concerns focus on the problem, such function is fulfilled by e.g. active coping, planning, problem solving, suppressing competitive activities, seeking instrumental support (Kozaka, 2010). The second concerns the regulation of emotions (e.g. minimizing danger, wishful thinking, positive expectations, humor, seeking emotional support) (Kozaka, 2010). Lazarus and Folkman's concept has been enriched with other coping methods, e.g. focus on approaching - avoidance (Endler and Parker, 1990), e.g. search vs information avoidance, acceptance vs helplessness. An important element was also the distinction of the role of positive emotions in the coping process and based on them coping focused on meaning, such as seeking benefits, setting adaptive goals, reformulating priorities (Folkman, 2008). The benefits of using these strategies, such as personal development, relate to goals, values and beliefs that are associated with spiritual coping (Folkman, 1997).

\subsection{Coping strategies in cancer}

Classifications of coping processes usually take one of two forms (Juczyński, 2000). The first of these focuses on counseling and directing the orientation and activity of a person to solve the problem and control the emotions associated with it. The second approach is focused on coping methods that express cognitive and behavioral strategies. The combination of both approaches is the classification of Moos and Schaefer (1993, after: Juczyński, 2000), who present an integrated approach to coping processes.

Understanding stress and dealing with cancer is usually closest to Lazarus and Folkman's transactional stress theory (1984). Disease as a stressful situation is also called distress, i.e. a multifactorial, unpleasant emotional experience with psychological, social and spiritual background (Holland, 1998). The goal of coping with cancer is to adapt to disease and treatment. 
The best-known model for dealing with the diagnosis of cancer includes five coping strategies: helplessness - hopelessness, anxiety preoccupation, denial / avoidance, acceptance and fighting spirit (Watson et al., 1988). Stoic acceptance, also called fatalism, expresses recognition of the seriousness of the disease and accepting it as what fate has brought. Denial, also called positive avoidance, means that the patient using this strategy does not believe in the severity of the disease and the threat it brings. Helplessness and hopelessness express passivity and surrender to the disease, and the patient believes that he cannot do anything about it. The attitude of the fighting spirit encourages us to treat the disease as challenge and a desire to fight it. Anxiety preoccupation is expressed through constant concern and thinking about the disease and assigning any change to the disease significance. The presented forms of mental adaptation constitute a construct that results from the combination of assessing the threat caused by the disease and methods of coping with the disease.

Active coping strategies are more often associated with better adaptation to the disease situation, and thus with patients' quality of life than less active strategies (e.g. Pearman, 2003; Kershaw et al., 2004; Juczyński and Chrestowska-Jabłońska, 1999), although it may depend on the specific situation of the patient, e.g. if it is not possible to remove the source of stress or reduce its intensity, avoidance strategies can also be adaptive. According to Lazarus (2000), none of the coping strategies are automatically more adaptive, and the level of its adaptability depends on the specific situation.

Chojnacka-Szawłowska, (2012) indicates two tasks needed to be implemented in the process of coping with the disease. The first is to deal with the disease itself and related problems, such as pain. The second task is dealing with life that has changed due to illness, among others securing a moderate emotional balance and maintaining a satisfactory self-image.

Some patients seek while others avoid information about their illness. Informationoriented behavior can be a stress coping strategy. The patient's approach to information about the disease has made it possible to distinguish two styles of cognitive coping (Juczyński, 2000). The first is the style of information search, which involves dealing with danger by seeking information about the threat, which reduces anxiety and uncertainty. This style is based on vigilant observation (monitoring) (Chojnacka-Szawłowska, 2012; Heszen-Niejodek, 1991). Searching for information about the disease is associated with a tendency to confront and combat negative factors.

The second style of coping is to avoid threat information. Information-avoiding patients tolerate uncertainty well, mainly due to distraction, while an excess of information causes fear (Heszen-Niejodek, 1991). This style is based on the suppression of warnings (blunting) (Chojnacka-Szawłowska, 2012; Heszen-Niejodek, 1991). Information avoidance is associated with a tendency to withdraw and flee. In the face of a serious illness, both confrontational and escape styles are more effective than passivity and resignation (Juczyński, 2000).

It is estimated that between 30 and 90 percent of people in difficulty turn to religion (Pargament, 1997). A form of coping with a difficult situation can be religious coping with stress, which means a process in which a person seeks meaning by referring to the religious sphere, i.e. God, the community of the Church or other believers (Pargament, 1997). The concept of religious coping with stress was based on the stress concept of Lazarus and Folkman (1984). Coping in this concept involves positive religious strategies, e.g., perceiving a stressful situation as an opportunity to approach God or seeking and giving 
spiritual support, and negative religious strategies, e.g., perceiving difficult events as a punishment from God (Pargament, 1997). Positive religious strategies are associated with a lower level of emotional distress and a lower severity of psychosomatic symptoms (Pargament, Koenig and Perez, 2000). However, the use of negative religious strategies is associated with many psychopathological symptoms, among others with anxiety disorder and depression (McConnel, Pargament, Ellison and Flannelly, 2006). Religion can be an important resource in dealing with cancer. In the study of patients suffering from prostate cancer and their wives, it turned out that women who used a strategy of dealing religiously together with their sick husbands had a greater decline in dysfunctional, impulsive problem solving. Such results were obtained only in couples turning to religion in dealing with prostate cancer (Yoshimoto, Ghorbani and Baer, 2006).

\section{APPRAISAL OF THE DISEASE}

The importance assigned to the disease by the patient depends, among others on the clinical form and severity of the disease, diagnosis, dynamics of symptoms and disease progression. Janowski, Steuden, Kuryłowicz and Nieśpiałowska-Steuden (2009) indicate that certain subjective variables are also important, such as the complex and dynamic cognitive structure referred to as the concept of the illness (Kulczycki, 1971), the picture of the disease (Heszen-Niejodek, 2000) and disease theory (Leventhal, Meyer, Nerenz, 1980). On the basis of transactional stress theory (Lazarus and Folkman, 1984), the assessment of the importance of one's own illness can be seen as one of the processes mediating between the stressful situation of the appearance of the disease and its effects (Janowski et al., 2009). To be able to talk about a stressful event, there must be a cognitive interpretation of the situation, i.e. primary appraisal (as harm / loss, threat or challenge). In the event of a health emergency, the initial appraisal may have an impact on the appraisal of coping options, the application of specific coping strategies and the effectiveness of solving the entire stressful relationship, taking into account somatic, psychological and social costs (McCrae, 1984).

Studies on the relationship between the primary assessment of a stressful situation and coping with stress by cancer sufferers were meta-analyzed (Franks and Roesch, 2006). Initial assessments were operationalized as a threat, challenge or obstacle / loss. Coping is defined as problem or emotion oriented strategies, as well as the general orientation of coping through approaching or avoiding. Assessment of the disease as a threat turned out to be related to problem-oriented coping. Illness as an obstacle / loss was associated with avoidance. Assessment of the disease as a challenge turned out to be related to problemfocused coping and coping through approaching.

\section{ACCEPTANCE OF THE DISEASE}

Chronic diseases, among others cancers, impose various restrictions in everyday life of patients. Reconciliation and adaptation to unavoidable changes can be difficult. The determinant of adaptation to life with a chronic disease is acceptance of the disease (Janowski, Kurpas, Kusz, Mroczek and Jedynak, 2013;). Acceptance of the disease means recognizing and understanding the limitations and losses associated with it (Basińska and Kasprzak, 2012). Therefore, the acceptance of the disease determines the emotional way of functioning in the disease and adapting to it, which is manifested in a low intensity of reactions and negative emotions related to the disease. The greater the acceptance of the disease, the better the adaptation and the less psychological discomfort. 
In the study of patients with breast cancer, accepting the reality of the situation they were confronted with allowed them to predict their higher emotional well-being (Carver et al., 1993). The study of Polish women (Kamińska et al., 2014) compared the degree of acceptance of the disease of patients with breast cancer depending on the type of treatment. The highest level of disease acceptance was observed in patients after radical mastectomy and subsequent hormone therapy. Lower disease acceptance was associated with breastconserving surgery and chemotherapy. The study of patients after mastectomy (Bąk-Sosnowska, Oleszko and Skrzypulec-Plinta, 2013) showed that greater acceptance of the disease situation is conducive to anxiety preoccupation and greater support provided to the patient by the family.

Greater acceptance of the disease has been associated with less anxiety and a greater propensity to reevaluate the difficult situation. Acceptance of the diagnosis of the disease by women with breast cancer allowed to predict better adaptation in the long term, as opposed to avoidance-oriented strategy, which was a predictor of greater fear of cancer recurrence (Stanton, Danoff-burg and Huggins, 2002).

\section{SOCIAL SUPPORT}

Interest in the issue of social support has been observed since the 1980s. The concept of support means access to various forms of assistance for a person in a difficult situation. According to Sęk and Cieślak (2011), initial research on social support indicated positive relationships between this phenomenon and health and dealing with difficult situations, but over time it turned out that support is not always unambiguously beneficial. Therefore, attempts were made to specify this concept and deeper theoretical analysis of this complex phenomenon.

Juczyński (2014) indicates two dominant concepts of social support. The first of these is a structural approach and includes objectively existing and available social networks that provide sources of support, such as family and friends. The second concept of support is a functional approach, that is, it relates the definition of social support to the function and quality of social relationships that are undertaken in difficult situations.

In stressful and crisis situations, people often seek and use social support. The impact of support on the crisis situation is explained by two effects: main (direct) and buffer (indirect). The main effect of support is that support directly contributes to adaptation to difficult situations by affecting stressors, or modifies the perception of stress. The buffer effect of social support means that support reduces tension, reduces stressors and mitigates the effects of stress (Juczyński, 2014). Works devoted to the topic of social support most often relate to its functional relationships with life stress (Sęk and Cieślak, 2011).

Social support can be understood and measured in three ways (Juczyński, 2014). The structural approach defines the properties of social networks, that is, the relationship between a person and his social environment. They are measured by assessing the size, density and structure of the network. The functional approach defines support through resources that are provided by others and help in a difficult situation. In this approach, questionnaire support is measured. The structural and functional approach to social support does not include the feeling of support by the recipient. The subjective assessment of support is included in the perceptual approach, which takes into account the feeling of being supported. It is measured using self-report questionnaires. 
Many studies on stress and its effects indicate that social support reduces stress levels and its negative effects. The positive effect of support on physical health is also confirmed (Ganster and Victor, 1988). Support affects health both directly and indirectly through cognitive and behavioral variables associated with immunity and cardiovascular reactivity (Knoll and Schwarzer, 2011).

In the study of mental and social resources and their relationship to well-being in cancer patients, the relationship between perceived availability of social support for subjective well-being, impact on well-being after 9 months and change in well-being over time was examined. Social support was important in terms of well-being and predicted well-being changes over time (Pinquart and Fröhlich, 2009).

In the study of variables most closely related to the quality of life of people suffering from advanced cancer (Rodríguez, Mayo and Gagnon, 2013), among 65 variables (individual and environmental factors, biological factors, symptoms, functions, perceived overall health) the most important related factor with social quality of life turned out to be social support. The following variables after social support, important for the quality of life were general health perceptions, energy, social functions, psychological and physical functions.

In the study of the importance of various types of support in coping with cancer (Michałowska-Wieczorek, 2006) social support and supersonic (transpersonal) support were included. Social support was understood as resources provided by other people, i.e. emotional and practical support as well as social integration. Transpersonal support means supersonic trust, expressing the spiritual life orientation of the individual. It refers to the resources of supersonic reality, identified with God, a higher power or the cosmos. In terms of perceived support, women achieved higher results than men in all support indicators, especially social integration and transpersonal trust. Social support was negatively linked to the destructive strategies of coping with cancer, i.e. helplessness-hopelessness and anxiety preoccupation. Transpersonal trust was positively associated with positive re-evaluation and fighting spirit, i.e. adaptive and active strategies in coping with the disease. In the men surveyed, practical support and transpersonal confidence explained 45 percent of the variation in terms of a lower propensity to use non-adaptive strategies for dealing with cancer. Social support explained 14 percent of the variability in adaptive coping strategies. The surprising result was that less social integration was associated with more active disease management. The use of strategies of helplessness and hopelessness in dealing with cancer by men was most strongly associated with a lack of practical support, i.e. specific help in everyday life matters. In women, adaptive coping strategies, i.e. the fighting spirit and positive reevaluation of the disease were positively associated with transpersonal trust and a sense of social integration. Helplessness-hopelessness and anxiety preoccupation have been associated with a lack of emotional support in women.

\section{CONCLUSIONS}

Cancer has a comprehensive impact on patients. It constantly generates stress through the symptoms and effects of the disease itself, unpleasant side effects of treatment, the need to change lifestyle and hospital stays, the need to wait for the results of diagnostic and control tests. The disease is also associated with confrontation with the fear of deterioration of health, being dependent on the environment and death. The presence of cancer affects the quality of human life in all areas. In the physical sphere, it causes the need to cope with 
pain, fatigue and other side effects of the disease and its treatment. In the social sphere, it causes limitations in family, friendly and professional contacts due to hospitalization and still perceiving cancer as a disease threatening and causing anxiety. In the mental area, cancer often causes anxiety and depressed mood and anger, and also affects self-image. In the spiritual area, the disease affects the sense of meaning in life. Adapting to the difficult situation of the disease facilitates the use of adaptive coping strategies, appraising the disease as a challenge rather than threat or loss, accepting the inevitable limitations in everyday life, and seeking and using various sources of support.

\section{REFERENCES}

Bąk-Sosnowska, M., Oleszko, K., Skrzypulec-Plinta, V. (2013). Adaptacja psychologiczna dojrzatych kobiet $w$ pierwszych dobach po zabiegu mastektomii. "Przeglad Menopauzalny”, 12(2).

Basińska, M. A., Kasprzak, A. (2012). Zwiazek między strategiami radzenia sobie ze stresem a akceptacją choroby w grupie osób chorych na łuszczycę. „Przegląd Dermatologiczny”, 99(6).

Carver, C. S., Pozo, C., Harris, S. D., Noriega, V., Scheier, M. F., Robinson, D. S., Ketcham, A. S., Mofflat, F. L., Clark, K. C. (1993). How coping mediates the effect of optimism on distress: a study of women with early stage breast cancer. "Journal of Personality and Social Psychology", 65.

Carver, C. S., Scheier, M. F., Weintraub, J. K. (1989). "Assessing coping strategies: a theoretically based approach. Journal of Personality And Social Psychology”, 56(2).

Chojnacka-Szawłowska, G. (2012). Psychologiczne aspekty przewlekłych chorób somatycznych. Warszawa: Vizja Press\&It.

De Walden-Gałuszko, K. (2011). Psychoonkologia w praktyce klinicznej. Warszawa: Wydawnictwo Lekarskie PZWL.

Endler, N. S., Parker, J. D. (1990). Multidimensional assessment of coping: a critical evaluation. “Journal of Personality and Social Psychology”, 58(5).

Folkman, S. (1997). Positive psychological states and coping with severe stress. "Social Science and Medicine”, 45(8).

Franks, H. M., Roesch, S. C. (2006). Appraisals and coping in people living with cancer: a meta-analysis. "Psycho-Oncology", 15(12).

Ganster, D. C., Victor, B. (1988). The impact of social support on mental and physical health. "British Journal of Medical Psychology”, 61(1).

Heszen-Niejodek, I. (2000). Radzenie sobie z choroba - przeglad zagadnień [w:] Heszen-Niejodek, I., red., Jak żyć z choroba, jak ja pokonać. Katowice: Wydawnictwo Uniwersytetu Śląskiego.

Heszen-Niejodek, I. (1991). Radzenie sobie z konfrontacją stresowa. „,Nowiny Psychologiczne”, $1-2$.

Hobfoll, E. S. (2006). Stres, kultura i społeczność. Gdańsk: Gdańskie Wydawnictwo Psychologiczne.

Holland, J. C., (1998). Social Views of Cancer and the Emergence of Psychooncology [w:] Holland J. C., red., Psycho-oncology. New York: Oxford: Oxford University Press.

Janowski, K., Kurpas, D., Kusz, J., Mroczek, B., Jedynak, T. (2013). Health-Related Behavior, Profile of Health Locus of Control and Acceptance of Illness in Patients Suffering from Chronic Somatic Diseases. PLoS ONE 8(5): e63920. DOI:10.1371/journal.pone.0063920. 
Janowski, K., Steuden, S., Kuryłowicz, J., Nieśpiałowska-Steuden, M. (2009). The DiseaseRelated Appraisals Scale. A tool to measure subjective perception of the disease situation [w:] K. Janowski, K., Steuden, S., red., Biopsychosocial aspects of health and disease. T. 1. Lublin: Centrum Psychoedukacji i Pomocy Psychologicznej.

Juczyński Z., Ogińska- Bulik, N. (2009). Narzędzia Pomiaru Stresu i Radzenia Sobie ze Stresem. Warszawa: Pracownia Testów Psychologicznych.

Juczyński, Z. (2000). Radzenie sobie ze stresem spowodowanym choroba nowotworowa [w:] De Walden-Gałuszko K., red., Psychoonkologia. Kraków: Biblioteka Psychiatrii Polskiej.

Juczyński, Z. (2009). Narzędzia Pomiaru w Promocji i Psychologii Zdrowia. Warszawa: Pracownia Testów Psychologicznych.

Juczyński, Z. (2014). Pomiar wsparcia społecznego - polska adaptacja Skali Znaczenia Innych [w:] Zasępa, E., Gałkowski, T., red., Oblicza psychologii klinicznej. Gdańsk: Gdańskie Wydawnictwo Psychologiczne.

Juczyński, Z., Chrestowska-Jabłońska, B. (1999). Strategie radzenia sobie z choroba nowotworowa: „Psychoonkologia”, 5.

Juczyński, Z., Szamburska, J., Czechowicz, E. (1997). Informowanie pacjenta o chorobie nowotworowej w opinii i praktyce lekarskiej. „,Nowotwory”, 47.

Kamińska, M., Ciszewski, T., Bronikowska, A., Ferańska, M., Pawlak-Warszawska, A., Paśnik, E. (2014). Acceptance of the illness and the quality of life of patients with breast cancer. "Polish Journal of Public Health", 124(1).

Kershaw, T., Northouse, L., Kritpracha, C., Schafenacker, A., Mood, D. (2004). Coping strategies and quality of life in women with advanced breast cancer and their family caregivers. "Psychology and Health", 19(2).

Knoll, N., Schwarzer, R. (2011). Prawdziwych przyjaciót...Wsparcie społeczne, stres, choroba i śmierć [w:] Sęk, H., Cieślak, R., red., Wsparcie społeczne, stres a zdrowie. Warszawa: Wydawnictwo Naukowe PWN.

Kozaka, J. (2010). Radzenie sobie ze stresem choroby - wspótczesne koncepcje teoretyczne. „Psychoonkologia”, 2.

Kübler-Ross, E. (1979). Rozmowy o śmierci i umieraniu. Poznań: Media Rodzina.

Kulczycki, M. (1971). Psychologiczne problemy człowieka chorego. Z zagadnień pracownika stużby zdrowia z pacjentem. Wrocław: Ossolineum.

Lazarus, R. S. (2000). Evolution of a model of stress, coping, and discrete emotions [w:] Rice, V. H., red., Handbook of Stress, Coping, and Health. Sage, Thousand Oaks, CA.

Lazarus, R. S., Folkman, S. (1984). Stress, Appraisal and Coping. New York: Springer.

Leventhal, H., Meyer, D., Nerenz, D. (1980). The common sense representation of illness danger [w:] Rachman, S., red., Contributions to medical psychology. New York: Pergamon.

McConnell, K. M., Pargament, K., Ellison, C. G., Flannelly, K. (2006). Examining the links between spiritual struggles and symptoms of psychopathology in a national sample. “Journal of Clinical Psychology”, 62(12).

McCrae, R. R. (1984). Situational determinants of coping responses: Loss, threat, and challenge. "Journal of Personality and Social Psychology", 46(4).

Pargament, K. I. (1997). The psychology of religion and coping. Theory, research, practice. New York-London: The Guilford Press.

Pargament, K. I., Koenig, H. G., Perez, L. M. (2000). The many methods of religious coping: Development and initial validation of the RCOPE. "Journal of Clinical Psychology", 56(4). 
Pearman, T. (2003). Quality of life and psychosocial adjustment in gynecologic cancer survivors. "Health Quality Life Outcomes", 20.

Pettingale, K. W. (1984). Coping and cancer prognosis. "Journal of Psychosomatic Research”, 28(5).

Pinquart, M., Fröhlich, C. (2009). Psychosocial resources and subjective well-being of cancer patients. "Psychology and Health" 24(4).

Schwarzer, R. (2001). Stress, resources, and proactive coping. "Applied Psychology: An International Review", 50.

Sęk, H., Cieślak, R. (2011). Wsparcie społeczne - sposoby definiowania, rodzaje i źródta wsparcia, wybrane koncepcje teoretyczne [w:] Sęk, H., Cieślak, R., red., Wsparcie społeczne, stres $i$ zdrowie. Warszawa: Wydawnictwo Naukowe PWN.

Stanton, A. L., Danoff-Burg, S., Huggins, M. E. (2002). The first year after breast cancer diagnosis: hope and coping strategies as predictors of adjustment. "Psycho-Oncology", 11(2).

Watson, M., Greer, S., Young, J., Inayat, Q., Burgess, C., Robertson, B. (1988). Development of a questionnaire measure of adjustment to cancer: the MAC scale. "Psychological Medicine", 18.

Yoshimoto, S. M., Ghorbani, S., Baer, J. M. (2006). Religious coping and problem-solving by couples faced with prostate cancer. "European Journal of Cancer Care”, 15(5).

DOI: $10.7862 /$ rz.2021.hss.18

The text was submitted to the editorial office: August 2020.

The text was accepted for publication: June 2021. 